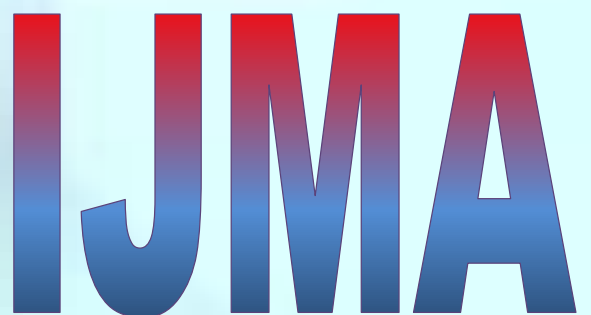

INTERNATIONAL

Journal of MEdical

\section{ARTS}

Volume 3, Issue 1 (Winter 2021)

http://ijma.journals.ekb.eg/

Print ISSN: 2636-4174

Online ISSN: 2682-3780

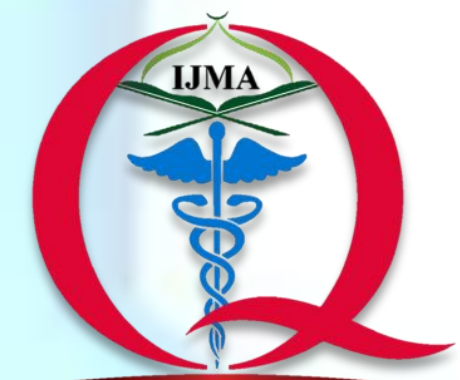

International Jounnal of Medical Arts

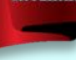




\section{About IJMA}

- International Journal of Medical Arts is the Official Journal of the Damietta Faculty of Medicine, Al-Azhar University, Egypt

- The First Issue was published in July 2019

- It is an International, Open Access, Double-blind, Peerreviewed Journal

- Published four times a year

- Published under the following license: Creative Commons Attribution-ShareAlike 4.0 International Public License (CC BY-SA 4.0). It had updated from the Creative Commons license [CC BY] in volume 2, Issue 4, October 2020

- The Egyptian Knowledge Bank hosts the web site of IJMA

- The Egyptian Knowledge Bank supports IJMA

- IJMA is indexed in the "Directory of Open Access Journals" Indexed on 15 January 2021.

- IJMA follows the regulations of the International Committee of Medical Journal Editors (list date 1/21/20)

- IJMA is a member of The International Society of Managing and Technical Editors

- IJMA is listed in Index Copernicus

- IJMA is listed in Publons, as EKB is an official partner with Clarivate Analytics
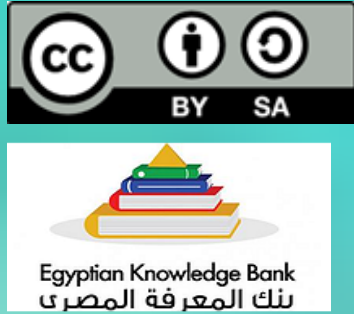

\section{DOAJ}

CMNE

ISMTE

INDEX COPERNICUS

publons 
International Journal of Medical Arts 2021; 3 [1]: 1172-1178.

Available online at Journal Website
https://ijma.journals.ekb.eg/
Main subject [Neurosurgery, Otorhinolaryngology]

Original article

\title{
Microscopic and Endoscopic Transoral Approaches for the Management of Craniocervical Chordomas
}

\author{
Mohammad Fathy Mohammad Eissa[1]; Mohamed Soleiman Mohamed Soleiman[2]; Gasser Hasan Al- \\ Shayal[2]; Tawfik Abdelaaty Elkho|[3]; Ibrahim Eldsoky[3]; Mohamed Ahmed Abdelwahid Ellabbad[2]
}

Department of Neurosurgery, Faculty of Medicine for Girls, Al-Azhar University, Egypt ${ }^{11]}$

Department of Neurosurgery, Faculty of Medicine, Al-Azhar University, Egypt [2]

Department of Otorhinolaryngology, Faculty of Medicine, Al-Azhar University, Egypt ${ }^{[3]}$

Corresponding author: Mohammad Fathy Mohammad Eissa

Email: mohammadfathyeissa@azhar.edu.eg

Submission date: Septermber 11, 2020; Revision date: January 07, 2020; Acceptance date: January 08, 2021

DOI: 10.21608/ijma.2021.42543.1165

ABSTRACT
Background: Craniocervical chordoma representing a challenge for surgeons. The endoscopic transoral approach is used for
treatment. Additional exposure is required. However, its benefits are not sufficiently addressed.
Aim: To evaluate the use of endoscopy in the transoral approach and the benefits of additional exposure in cases of
craniocervical chordomas.
Patients and Methods: in this study, 12 patients had a confirmed diagnosis of chordoma after histopathological examination
due to the presence of craniocervical destructive lesions. The author performed all surgical cases using a microscopic
transoral approach in 6 patients, an endoscopic-assisted microscopic transoral approach in 3 patients, and a purely
endoscopic transoral approach in 3 patients. Eight patients required posterior cervical fusion according to the extent
of instability. Preoperative and postoperative data were collected, including radiological examination and clinical
status data.
Results: in this study, 12 patients were evaluated clinically and radiologically. It was found that the use of endoscopic assistance
in the microscopic transoral approach, or the use of the purely endoscopic transoral approach, added greater angles
of exposure of the tumors that could not be reached when using a microscope alone. This led to greater tumor removal
and excision with the same precautions and safety for the patient using these approaches compared with the use of
the microscopic approach alone. The use of endoscopy alone minimized the incision of the posterior pharyngeal wall
and led to good healing, which is an important goal in this field and additional angles of view.
Conclusion: The use of endoscopy either for assistance in the microscopic transoral approach or alone led to the safe
implementation and greater extent of tumor removal and excision. We recommend the use of endoscopy in such
cases.

Keywords: Transoral; Endoscopic; Craniocervical; Chordoma; Transsphenoidal.

This is an open-access article registered under the Creative Commons, ShareAlike 4.0 International license [CC BY-SA 4.0] [https://creativecommons.org/licenses/by-sa/4.0/legalcode.

Please cite this article: Eissa MFM, Soleiman MSM, Al-Shayal GH, Elkhol TA, Eldsoky I, Ellabbad MAA. Microscopic and Endoscopic Transoral Approaches for The Management of Craniocervical Chordomas. IJMA 2021; 3[1]: 1172-1178. DOI:10.21608/ijma.2021.42543.1165

* Main subject and any subcategories have been classified according to the research topic. 


\section{INTRODUCTION}

Chordomas are slowly growing tumors that arise from the primitive notochord remnants. They are found predominantly in both sacrococcygeal and clivus regions. Although they appear as encapsulated soft tissue tumors, they can infiltrate surrounding bones along lines with the least resistance [1]. Despite great surgical advances, the excision of such tumors remains a great challenge for many neurosurgeons. These tumors' recurrence rate remains high even if complete resection is achieved, as these tumors occur in the previously mentioned critical anatomical regions [2]. Multiple factors have been found to affect treatment choice for anterior craniovertebral junction compression; these factors include reducibility, compression direction and mechanics, cause of compression, and presence of ossification centers. If reducibility is detected, removing the compression is strongly recommended through the transoral route ${ }^{[3]}$.

Most neurosurgeons prefer the transoral approach for handling ventral craniovertebral junction pathologies. This approach offers a short working distance to the craniovertebral junction [CVJ]. Moreover, it is not restricted by the nasal cavity, palate, or pterygoid plates. However, as a part of modern neurosurgery advances, endoscopes have gained additional popularity[4].

As a result of the increasing experience in endoscopic trans-sphenoidal pituitary surgery, the application of both endoscopic-assisted and purely endoscopic techniques for CVJ pathologies has been developed. Many neurosurgeons prefer to use endoscopy to access the ventral craniovertebral junction as it offers a significantly larger working corridor than the traditional microscopic approach[3].

\section{AIM OF THE WORK}

To evaluate the use of endoscopy in the transoral approach and the benefits of additional exposure in cases of craniocervical chordomas.

\section{PATIENTS AND METHODS}

Study design: This retrospective study included patients diagnosed with anterior craniocervical chordoma after it was confirmed by histopathological examination.
The study was conducted at Al-Azhar University Hospitals and Nasr City Health Insurance Hospital between Jan 2016 and July 2019.

A total of 12 patients with craniocervical chordomas were included. Patients with other anterior CVJ pathologies, patients unfit for anesthesia, and patients lost to follow-up were excluded from the current study.

Ethical considerations: A written formal consent was obtained from all patients before the procedure after explaining the advantages, steps, and drawbacks of each approach.

Patient preparation: All patients were subjected to an evaluation for complete medical history, a thorough neurological examination, and routine preoperative laboratory investigations. Tumour extent was assessed via MRI or CT scans.

\section{The surgical procedure:}

For the microscopic approach, the patient was placed in a supine position, the head was slightly extended, and the skull was fixed with Mayfield skull clamps. After that, the anterior tubercle of $\mathrm{C} 1$ was palpated. A midline incision of the oropharyngeal mucosa was performed until the prevertebral muscles [longus coli] were reached. In some cases, an incision of the soft palate was created on one side of the uvula to gain additional exposure. Dissection was performed to expose the anterior longitudinal ligament. The microscope was introduced after lateral retraction of both the pharyngeal mucosa and muscles. The anterior longitudinal ligament was dissected from the bone to expose the anterior arch of $\mathrm{C} 1$ and the clivus's inferior border of the tumor itself if the bone infiltrated. A 12-15 mm segment of the anterior arch of $\mathrm{C} 1$ was removed with a drill to expose the base of the odontoid process or underlying tumour tissue. Odontoidectomy was needed in some cases when the tumour was located posterior to the dens, and the procedure was performed using a high-speed drill. The tumour tissues were removed using tumour rongeurs. Then, the alar and apical ligaments were resected if the tumour tissues expanded deep to these ligaments. After that, the posterior longitudinal ligament was removed. The dura's decompression was considered adequate 
when the dura pulsated freely and when the lateral dural curvature could be seen bilaterally. If durotomy occurred accidentally, great effort was made to perform a water-tight closure to prevent CSF leakage. Good hemostasis and fat interposition or fibrin glue were occasionally used after closure. Closure of the oropharyngeal wall was performed in a 3-layer fashion using Vicryl $3 / 0$ sutures. Endoscopy was performed to provide greater exposure and visualization without the additional morbidity of splitting the soft palate as occurred in the microscopic cases. With the improvements in endoscopic surgical instruments and surgeons' increasing familiarity and facility, endoscopy is a potentially feasible option in selecting odontoid pathology cases above the nasopalatine line.

Regarding the endoscopic-assisted cases, the procedure started with the use of a microscope, and the endoscope was used to expose additional areas that were difficult to expose with the microscope.

Postoperative care: Patients were intubated for at least 24 hours, and intubation was not removed until tongue swelling subsided. Oral and nasal asepsis was maintained. Patients were placed in a semi-sitting position to avoid the pooling of saliva over the pharyngeal incision. Oral feeding was not allowed for 5 days after the operation. Patients received nutrition via a feeding tube or an intravenous route. All patients were started on injectable steroids for 3 days postoperatively to decrease pharyngeal, palatal, and glossal edema.

Follow-up: Regular follow-up visits were scheduled 1-week after discharge and then every month for the first 3 months after the operation. After that, a follow-up visit was arranged every 3 months. Patients were assessed clinically and radiologically [MRI or $\mathrm{CT}]$ if indicated.

Statistical analysis: The collected data were coded, processed, and analyzed using SPSS [Statistical Package for Social Sciences] version 22 for Windows ${ }^{\circledR}$ [SPSS Inc., Chicago, IL, USA]. Qualitative data are presented as numbers [frequencies] and percentages. Quantitative data were tested for normality with the KolmogorovSmirnov test and are expressed as medians [ranges].
Case Presentation: A female patient, 59 years old, presented with neck pain and dysphagia, and $\mathrm{MRI}$ of the craniocervical junction showed a C1-C2 infiltrative lesion. She underwent surgery using the microscopic transoral approach as well as posterior occipitocervical fixation, as shown in figure [1].

\section{RESULTS}

The included patients' mean age was 57.33 years [range, $38-73$ years]. We included 8 males [66.67\%] and 4 females [33.33\%]. The most common presenting symptom was neck pain [11 patients; $91.67 \%$ ], followed by dysphagia [2 patients; 16.67\%] and weakness [2 patients; $16.67 \%$ ]. Regarding the radiological findings, a destructive C1-2 space-occupying lesion was detected in 9 patients [75\%], whereas an infiltrative lesion was present in 3 patients [25\%]. A preoperative C1-2 shift was present in 2 patients [16.67\%]. Regarding the approach used in our patients, the purely endoscopic approach was performed in 3 patients [25\%], while the endoscopic-assisted procedure was performed in the other 3 patients [25\%]. Additionally, the microscopic approach was performed in the remaining 6 patients [50\%]. The endoscopic approach provided a wider view than the other approaches during the operation. In addition, the pharyngeal incision was much smaller with the endoscopic approach $[3 \mathrm{~cm}]$ than with the microscopic approach $[5 \mathrm{~cm}]$. The operative time ranged between 3 and 5 hours for the anterior approach, and it did not differ significantly among the three approaches applied in our study. The arch of $\mathrm{C} 1$ was preserved in 1 patient [8.33\%].

Regarding the extent of surgical resection, gross total excision was achieved in 10 patients [83.33\%], while partial excision was achieved in 2 patients [16.67\%]. Postoperatively, a feeding tube was needed in all patients [100\%]. Our patients were followed for 15 months [range, 8-24].

Regarding the postoperative complications, it was evident that the purely endoscopic patients experienced no complications. Nevertheless, other patients had the following complications: dysphagia [2 patients; $16.67 \%$ ], dysphonia [8.33\%], weakness [16.67\%], voice hoarseness [16.67\%], and limited neck movement [16.67\%] [Table 1]. 

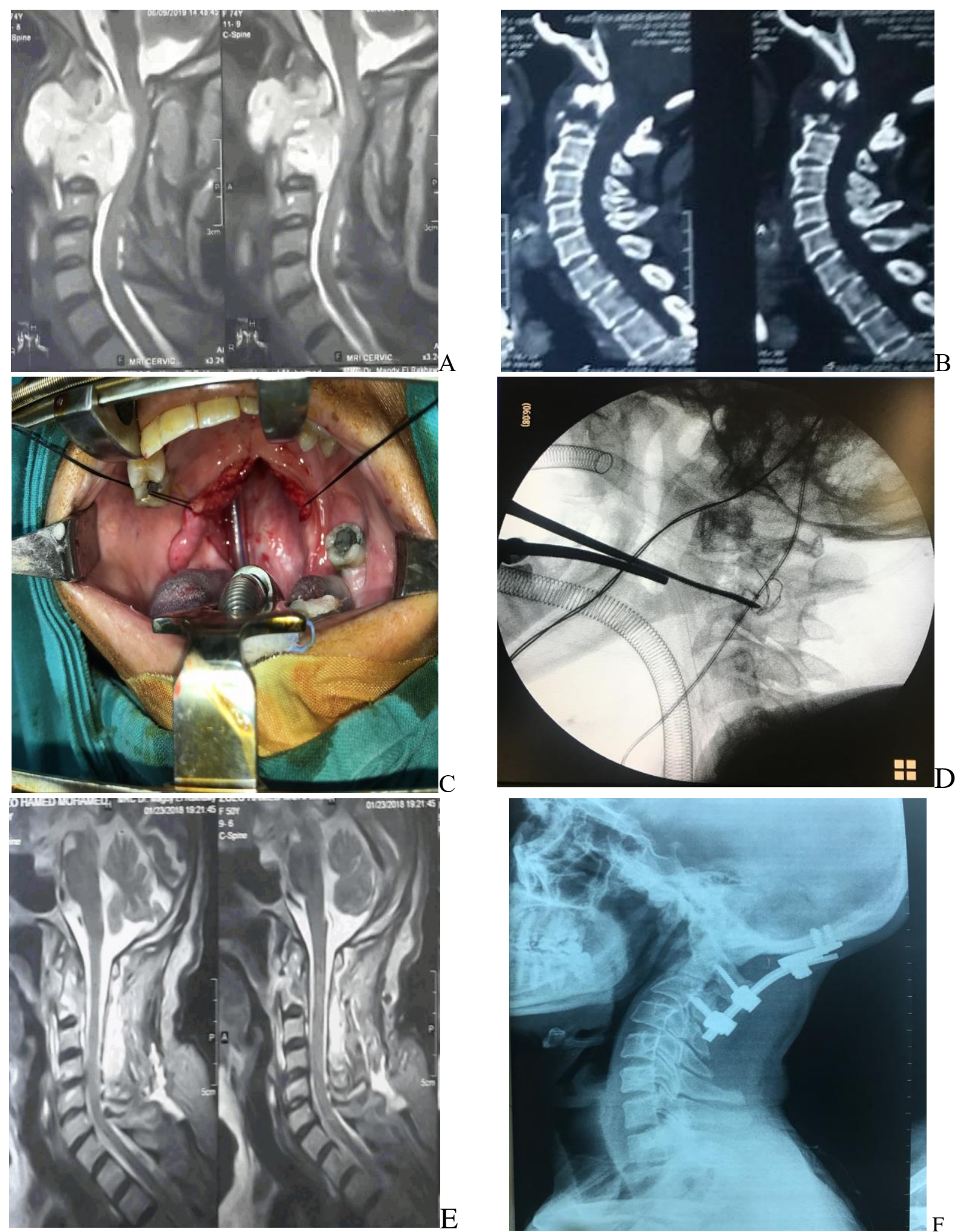

Figure [1] A: Preoperative sagittal view of T1-weighted MRI with contrast showing C1-2 chordoma compressing the spinal cord. B: Preoperative sagittal view of bone-window CT showing C1-2 chordoma infiltrating the bone. C: Photo of the open mouth with a soft palate incision to expose the upper limit of the tumor, which bulges from the pharyngeal wall. D: Intraoperative lateral view of a C-arm image showing Landmark after removing the posterior part of the tumor. E: Postoperative sagittal view of MRI with contrast with near-total excision of the tumor and good decompression. F: Postoperative lateral view of PXR with occipitocervical fixation. 
Table [1]: The data of our study cases.

\begin{tabular}{|c|c|c|c|c|c|c|c|c|c|c|c|c|}
\hline Cases & Age & Sex & $\begin{array}{l}\text { Main } \\
\text { symptom }\end{array}$ & Radiology & Approach & $\begin{array}{l}\text { C1 arch } \\
\text { preservation }\end{array}$ & $\begin{array}{l}\text { Degree } \\
\text { of } \\
\text { resection }\end{array}$ & $\begin{array}{l}\text { Need for } \\
\text { tracheostomy }\end{array}$ & $\begin{array}{l}\text { Operative } \\
\text { time }\end{array}$ & $\begin{array}{l}\text { Need } \\
\text { for } \\
\text { feeding } \\
\text { tube }\end{array}$ & Complications & $\begin{array}{l}\text { Follow- } \\
\text { up } \\
\text { [months] }\end{array}$ \\
\hline $\begin{array}{l}\text { Case } \\
1\end{array}$ & 73 & $\mathrm{M}$ & Neck Pain & $\begin{array}{l}\text { C1-2 } \\
\text { Destructive } \\
\text { SOL }\end{array}$ & $\begin{array}{l}\text { Combined } \\
\text { Mic Ant } \\
+ \text { Post Fix }\end{array}$ & No & Partial & No & $3 \mathrm{~h}$ & Yes & $\begin{array}{l}\text { Dysphagia } 2 \\
\text { months }\end{array}$ & 20 mon \\
\hline $\begin{array}{l}\text { Case } \\
2\end{array}$ & 59 & $\mathrm{~F}$ & Neck Pain & $\begin{array}{l}\text { C1-2 } \\
\text { Destructive } \\
\text { SOL }\end{array}$ & $\begin{array}{l}\text { Combined } \\
\text { Mic Ant } \\
+ \text { Post Fix }\end{array}$ & No & $\begin{array}{l}\text { Gross } \\
\text { Total }\end{array}$ & No & $3 \mathrm{~h}$ & Yes & $\begin{array}{l}\text { Dysphonia } 3 \\
\text { months }\end{array}$ & $16 \mathrm{mon}$ \\
\hline $\begin{array}{l}\text { Case } \\
3\end{array}$ & 57 & M & Dysphagia & $\begin{array}{l}\text { C2 } \\
\text { Infiltrative } \\
\text { SOL }\end{array}$ & $\begin{array}{l}\text { Endo } \\
\text { Anterior }\end{array}$ & Yes & $\begin{array}{l}\text { Gross } \\
\text { Total }\end{array}$ & No & $4 \mathrm{~h}$ & Yes & No & 14 mon \\
\hline $\begin{array}{l}\text { Case } \\
4\end{array}$ & 64 & M & $\begin{array}{c}\text { Pain } \quad+ \\
\text { Weakness }\end{array}$ & $\begin{array}{l}\text { C1-2 } \\
\text { Destructive } \\
\text { SOL }\end{array}$ & $\begin{array}{l}\text { Combined } \\
\text { Endo Ant } \\
+ \text { Post Fix }\end{array}$ & No & $\begin{array}{l}\text { Gross } \\
\text { Total }\end{array}$ & No & $4 \mathrm{~h}$ & Yes & Weakness & 17 mon \\
\hline $\begin{array}{l}\text { Case } \\
5\end{array}$ & 67 & M & Neck Pain & $\begin{array}{l}\text { C1-2 } \\
\text { Destructive } \\
\text { SOL }\end{array}$ & $\begin{array}{l}\text { Combined } \\
\text { Ass Ant } \\
+ \text { Post Fix }\end{array}$ & No & $\begin{array}{l}\text { Gross } \\
\text { Total }\end{array}$ & No & $5 \mathrm{~h}$ & Yes & $\begin{array}{l}\text { Hoarseness } 2 \\
\text { months }\end{array}$ & $9 \mathrm{mon}$ \\
\hline $\begin{array}{l}\text { Case } \\
6\end{array}$ & 49 & $\mathrm{~F}$ & Neck Pain & $\begin{array}{l}\text { C1-2 } \\
\text { Infiltrative } \\
\text { SOL }\end{array}$ & $\begin{array}{l}\text { Endo } \\
\text { Anterior }\end{array}$ & No & $\begin{array}{l}\text { Gross } \\
\text { Total }\end{array}$ & No & $4 \mathrm{~h}$ & Yes & No & 19 mon \\
\hline $\begin{array}{l}\text { Case } \\
7\end{array}$ & 43 & M & Neck Pain & $\begin{array}{l}\text { C1-2 } \\
\text { Destructive } \\
\text { SOL }\end{array}$ & $\begin{array}{l}\text { Combined } \\
\text { Mic Ant } \\
+ \text { Post Fix }\end{array}$ & No & $\begin{array}{l}\text { Gross } \\
\text { Total }\end{array}$ & Yes & $3 \mathrm{~h}$ & Yes & $\begin{array}{l}\text { Limited Neck } \\
\text { Movement }\end{array}$ & 12 mon \\
\hline $\begin{array}{l}\text { Case } \\
8\end{array}$ & 55 & $\mathrm{~F}$ & Neck Pain & $\begin{array}{l}\text { C1-2 } \\
\text { Infiltrative } \\
\text { SOL }\end{array}$ & $\begin{array}{l}\text { Endo } \\
\text { Anterior }\end{array}$ & No & $\begin{array}{l}\text { Gross } \\
\text { Total }\end{array}$ & No & $4 \mathrm{~h}$ & Yes & No & 24 mon \\
\hline $\begin{array}{l}\text { Case } \\
9\end{array}$ & 69 & M & Neck Pain & $\begin{array}{l}\text { C1-2 } \\
\text { Destructive } \\
\text { SOL }\end{array}$ & $\begin{array}{l}\text { Combined } \\
\text { Mic Ant } \\
+ \text { Post Fix }\end{array}$ & No & Partial & No & $3 \mathrm{~h}$ & Yes & Dysphagia & $8 \mathrm{mon}$ \\
\hline $\begin{array}{l}\text { Case } \\
10\end{array}$ & 58 & M & $\begin{array}{l}\text { Pain }{ }^{+} \\
\text {Dysphagia }\end{array}$ & $\begin{array}{l}\text { C1-2 } \\
\text { Destructive } \\
\text { SOL }\end{array}$ & $\begin{array}{l}\text { Combined } \\
\text { Endo Ant } \\
+ \text { Post Fix }\end{array}$ & No & $\begin{array}{l}\text { Gross } \\
\text { Total }\end{array}$ & No & $4 \mathrm{~h}$ & Yes & Weakness & 17 mon \\
\hline $\begin{array}{l}\text { Case } \\
11\end{array}$ & 56 & M & Neck Pain & $\begin{array}{l}\text { C1-2 } \\
\text { Destructive } \\
\text { SOL }\end{array}$ & $\begin{array}{l}\text { Combined } \\
\text { Ass Ant } \\
+ \text { +Post Fix }\end{array}$ & No & $\begin{array}{l}\text { Gross } \\
\text { Total }\end{array}$ & No & $5 \mathrm{~h}$ & Yes & $\begin{array}{l}\text { Limited Neck } \\
\text { Movement }\end{array}$ & $18 \mathrm{mon}$ \\
\hline $\begin{array}{l}\text { Case } \\
12\end{array}$ & 38 & $\mathrm{~F}$ & $\begin{array}{c}\text { Pain } \quad+ \\
\text { Weakness }\end{array}$ & $\begin{array}{l}\text { C1-2 } \\
\text { Destructive } \\
\text { SOL }\end{array}$ & $\begin{array}{l}\text { Combined } \\
\text { Ass Ant } \\
+ \text { Post Fix }\end{array}$ & No & $\begin{array}{l}\text { Gross } \\
\text { Total }\end{array}$ & No & $5 \mathrm{~h}$ & Yes & $\begin{array}{l}\text { Transient } \\
\text { Hoarseness }\end{array}$ & $11 \mathrm{mon}$ \\
\hline
\end{tabular}

Endo: Endoscopic, Ant: Anterior, Post Fix: Posterior Fixation, Mic: Microscopic, Ass: Assisted Endoscopic

\section{DISCUSSION}

Until recently, most CVJ pathologies were managed via decompression of the foramen magnum, and stabilization was also performed in unstable cases ${ }^{[5,6]}$; however, the transoral approach has become the main procedure used for CVJ ventral decompression ${ }^{[7,8]}$. This transoral approach has many advantages; first of all, it allows access to ventral CVJ pathology. Second, the head is placed in an extended position and thus decreases brain stem angulation during surgery. Moreover, there is a minimal chance of injury to other structures, including the Eustachian tube, vidian nerve, and carotid artery, which are at great risk with applying the transnasal route. Finally, the surgical incision is created at the avascular median raphe and clivus ${ }^{[9]}$. However, many drawbacks have been reported with this approach, including inadequate lateral margin exposure and a lack of proximal control over the vertebral artery. Besides, incision of the dura overlying the clivus may lead to excessive hemorrhage, which may be difficult to control[10].

With the introduction of endoscopy, the limitations of TOA can be overcome. Owing to its optical and physical characters, endoscopy can provide a wide-angle panoramic view in this narrow surgical corridor. Hence, it can be easily applied for ventral CVJ pathologies ${ }^{[4]}$.

The current study was conducted at Al-Azhar University Hospitals and aimed to evaluate the use of endoscopy in the transoral approach and the benefits of additional exposure in cases of craniocervical chordomas. We included 12 patients with a mean age of 57.33 years. Eight of our patients were male, while the remaining 4 patients were female. Another study evaluated the application of the endoscopic-assisted transoral approach in CVJ chordomas. The authors included 7 patients with a mean age of 35 years [range, 11 78]: 5 males and 2 females ${ }^{[3]}$.

In the current study, the most common 
presenting symptom was neck pain [11 patients; 91.67\%], followed by dysphagia [2 patients; 16.67\%] and weakness [2 patients; 16.67\%]. Another study that investigated the transoral approach's outcomes in CVJ pathologies reported that neck pain was the most common complaint [37 patients; $97.36 \%$ ], which is in line with the results of our study. Other manifestations included myelopathy [31 patients; $81.58 \%$ ], sensory deficits [16 patients; 42.11\%], gait disturbances [15 patients; $39.47 \%$ ], cranial nerve palsies [7 patients; $18.42 \%$ ], nystagmus [4 patients; 10.53\%], and radiculopathy [1 patient; $2.63 \%]^{10]}$.

Endoscopy can provide a wide surgical view. Therefore, a small pharyngeal incision can be achieved [4]. This phenomenon was also noticed in our study, as the length of the pharyngeal incision was approximately $3 \mathrm{~cm}$ in the endoscopic patients, while it was approximately $5 \mathrm{~cm}$ in the microscopic patients.

A previous study reported that the application of neuroendoscopy for CVJ significantly improved exposure without compromising surgical freedom ${ }^{[4]}$. This was also observed in our study.

In a cadaveric study, the authors quantified the surgical volume gained by this approach. Exposure of the posterior pharyngeal area was significantly enhanced with the use of the endoscope [606.5 \pm $127.4 \mathrm{~mm}^{3}$ ] compared to the use of the operating microscope [425.7 $\left.\pm 100.8 \mathrm{~mm}^{3}\right]$, without having any effect on surgical freedom. Furthermore, the extent of clivus exposure was significantly improved with the endoscope $[9.5 \pm 0.7 \mathrm{~mm}]$ compared with the operating microscope $[2.0 \pm 0.4 \mathrm{~mm}]^{[11]}$.

The operative time ranged between 3 and 5 hours for the anterior approach, and it did not differ significantly among the three approaches applied in our study. Other authors reported a significantly longer operative time with the endoscopic technique [9 hours], but the authors attributed this prolongation to surgical experience and wide tumor margins that needed extra caution[12].

Another study reported that the endoscopicassisted approach achieved complete CVJ decompression and that good bone fusion was accomplished as demonstrated by postoperative X- ray, CT scan, and MR imaging[3].

Regarding the morbidity encountered in our series, dysphagia occurred in 2 patients [16.67\%], whereas dysphonia was present in 1 patient [8.33\%]. Besides, weakness was detected in 2 patients [16.67\%], voice hoarseness occurred in 2 patients [16.67\%], and limited neck movement was reported in 2 patients [16.67\%]. All these complications were encountered in either the microscopic- or endoscopic-assisted group. However, the three patients who underwent the purely endoscopic technique experienced no postoperative complications. Moreover, no cases of perioperative mortality were reported in our study.

Many studies have reported the advantages of neuroendoscopy. First, it provides unlimited surgical access to the CVJ. Moreover, palatal splitting is avoided. Therefore, less postoperative morbidity is anticipated[13,14]. A previous study noted that oropharyngeal complications were significantly more common in patients who underwent palatal splitting [75\%] than patients who did not [15.4\%]. Therefore, the authors recommend not performing this step unless it is necessary[15].

Landeiro and his colleagues reported that CSF leakage occurred in only one case [2.36\%], and it was detected and repaired during the same microscopic operation [10]. This complication was not encountered in our study. The other reported morbidities in the previously mentioned study included 3 pulmonary infection cases [7.89\%]. Mortality was encountered in one case [2.36\%] due to pulmonary embolism[10].

A previous case report published data regarding a case of axial chordoma, which was managed with the endoscopic approach. The authors reported no immediate or delayed neurological sequelae, CSF leakage, or infection[12]. Lack of 3-D perception of the visual field is the main disadvantage of endoscopy; however, it was not a limiting factor [4].

Conclusion: Endoscopy either for assistance in the microscopic transoral approach or alone led to the safe implementation and greater extent of tumor removal and excision. We recommend the use of endoscopy in such cases. 


\section{Financial and Non-financial Relationships and Activities of Interest}

None

\section{ACKNOWLEDGEMENTS}

The authors acknowledge all staff members of the neurosurgery departments in Al-Azhar University Hospitals and Nasr City Insurance hospital for their support and help during this work.

\section{REFERENCES}

1. Hyun S-J, Kim J-W, Kim K-J, Jahng TA, Roh SW, Ra YS, Kim HJ, Rhim SC. Long-term results following surgical resection of chordomas in the craniocervical junction and the upper cervical spine: review of 12 consecutive cases. Operative Neurosurgery [Hagerstown]. 2018 Feb 1; 14 [2]: 112-120. doi: 10.1093/ons/opx082

2. Colli BO, Al-Mefty O. Chordomas of the craniocervical junction: follow-up review and prognostic factors. J Neurosurg. 2001; 95[6]:933-43. doi: 10. 3171/jns.2001.95.6.0933

3. Visocchi M, Doglietto F, Della Pepa GM, Esposito G, La Rocca G, Di Rocco C, Maira G, Fernandez E. Endoscope-assisted microsurgical transoral approach to the anterior craniovertebral junction compressive pathologies. Eur Spine J. 2011; 20 [9]: 1518-25. doi: 10.1007/s00586-011-1769-7

4. Pillai $P$, Baig MN, Karas CS, Ammirati M. Endoscopic Image-Guided Transoral Approach to the Craniovertebral Junction: An Anatomic Study comparing surgical exposure and surgical freedom obtained with the endoscope and the operating microscope. Neurosurgery. 2009 May; 64 [5 Suppl 2]:437-42. doi: 10.1227/01.NEU. $0000334050.45750 . C 9$

5. da Silva JG. Basilar impression and Arnold-Chiari malformation. Neurochirurgia. 1992; 35[06]:18995. doi: $10.1055 / \mathrm{s}-2008-1052276$

6. Zileli M, Cagli S. Combined anterior and posterior approach for managing basilar invagination associated with type I Chiari malformation. J Spinal Disord Tech. 2002 Aug;15[4]:284-9. doi: 10.1097/00024720-200208000-00004

7. Goel A, Bhatjiwale M, Desai K. Basilar invagination: a study based on 190 surgically treated patients. J Neurosurg. 1998; 88[6]:962-8.doi: 10.3171/jns. 1998.88.6.0962
8. Di Lorenzo N. Craniocervical junction malformation treated by transoral approach. A survey of 25 cases with emphasis on postoperative instability and outcome. Acta neurochirurgica. 1992; 118 [3-4]:112-6. doi: 10.1007/BF01401296

9. Signorelli F, Costantini A, Stumpo V, Conforti G, Olivi A, Visocchi M. Transoral Approach to the Craniovertebral Junction: A Neuronavigated Cadaver Study. New Trends in Craniovertebral Junction Surgery: Springer; 2019. p. 51-5.

10. Landeiro JA, Boechat S, Christoph Dde H, Gonçalves MB, Castro Id, Lapenta MA, Ribeiro $\mathrm{CH}$. Transoral approach to the craniovertebral junction. Arquivos de neuro-psiquiatria. 2007; 65 [4B]: 1166-71. doi: 10.1590/s0004-282x2007 000700014

11. McGirt MJ, Attenello FJ, Sciubba DM, Gokaslan ZL, Wolinsky J-P. Endoscopic transcervical odontoiddectomy for pediatric basilar invagination and cranial settling: report of 4 cases. J Neurosurg: Pediatrics. 2008; 1[4]:337-42. doi: 10. 3171/ PED/2008/1/4/337

12. Taran S, Yusof A, Yusof M. Endoscopic transoral resection of an axial chordoma: a case report. Malays Orthop J. 2015; 9 [3]:75.doi: 10.5704/ MOJ.1511.015

13. Kassam AB, Snyderman C, Gardner P, Carrau R, Spiro R. The expanded endonasal approach: a fully endoscopic transnasal approach and resection of the odontoid process: technical case report. Neurosurgery. 2005; 57 [suppl_1]: E213E. doi: 10.1227/01.neu.0000163687.64774.e4

14. Jho H-D, Ha H-G. Endoscopic endonasal skull base surgery: Part 3-The clivus and posterior fossa. Minim Invasive Neurosurg. 2004; 47[01]:16-23. doi: $10.1055 / \mathrm{s}-2004-818347$

15. Jones D, Hayter J, Vaughan E, Findlay G. Oropharyngeal morbidity following transoral approaches to the upper cervical spine. Int J Oral Maxillofacial Surg. 1998; 27 [4]:295-8. doi: 10. 1016/s0901-5027(05)80618-6 


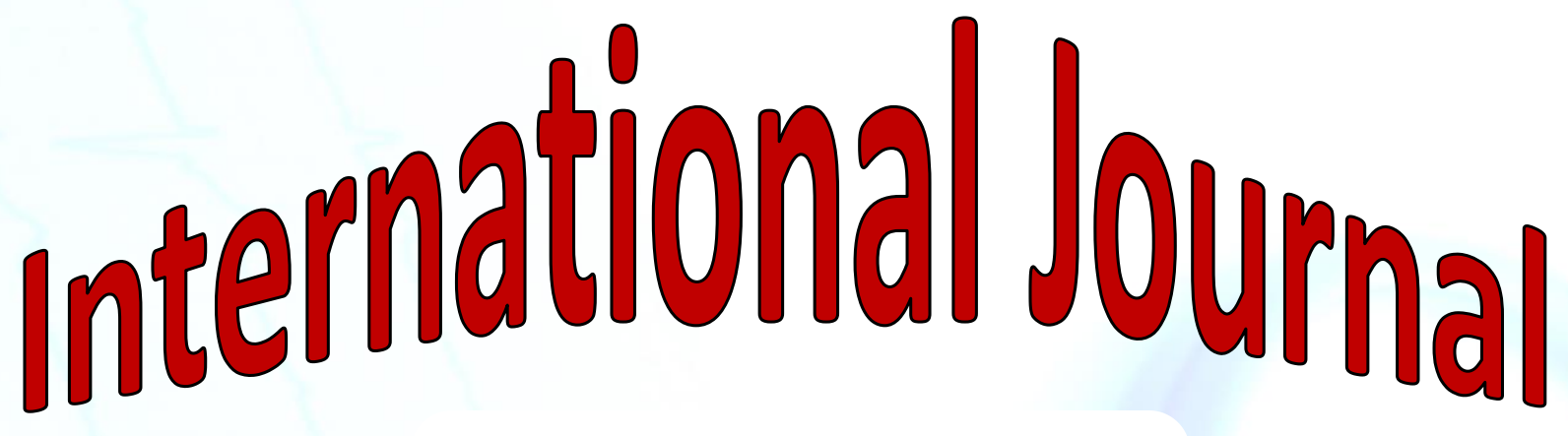

https://ijma.journals.ekb.eg/

Print ISSN: 2636-4174

Online ISSN: 2682-3780

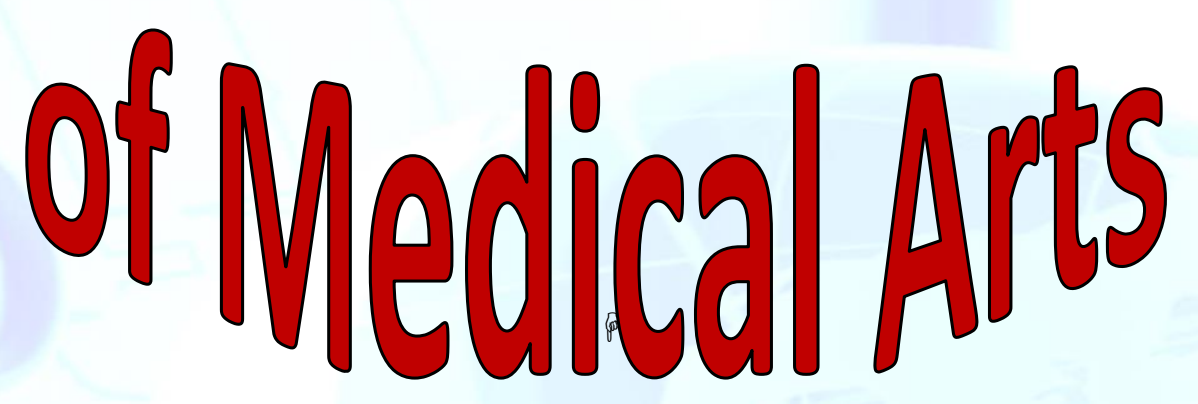

